\title{
Teaching Mark through a postcolonial optic
}

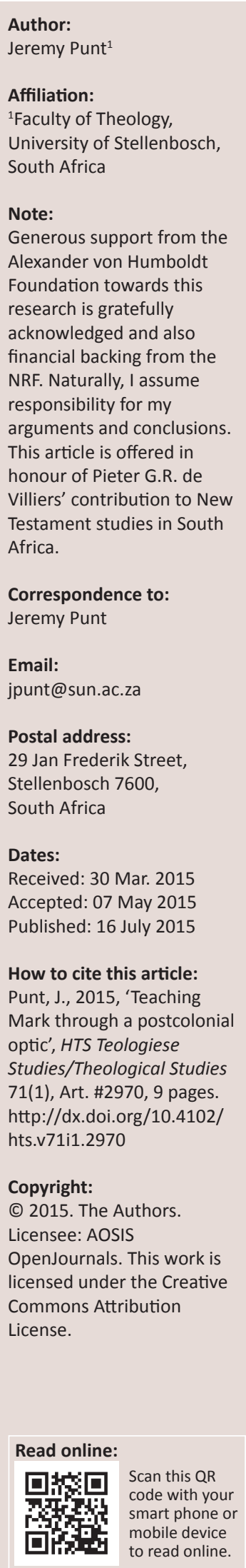

This contribution explores the potential value of a postcolonial approach for teaching Mark's gospel. Investigating a number of texts from the gospel, it asks to what extent a postcolonial optic implies a different approach to the gospel, what it adds and where challenges exist. Teaching with a postcolonial optic entails framing the gospel in its 1st-century imperial context and focusing on the ambivalence and ambiguity of imperial rule, investigating texts with attention to hybridity and mimicry in particular. Teaching the Gospel of Mark through a postcolonial optic opens up new possibilities for interpretation and contextualisation, but at the same time poses certain challenges, pedagogically and otherwise.

\section{Introduction}

Biblical scholarship over the last decade or two has shown increasing interest in empire and postcolonialism. Notwithstanding a rather slow uptake of postcolonialism in the two-thirds or majority world biblical scholarship (Punt 2006), publications - some of which are referred to below - increasingly appear which deal with imperial concerns and engage in postcolonial discourse. At the best of times, postcolonial work is in close concert with concerns about empire. But empire (or anti-empire) studies and postcolonial studies are not one and the same. Postcolonial work's uneasy relationship in various ways to matters imperial, in theoretical as well as pragmatic impulses, provides both perspective and challenges. The arguably different and wider reach of postcolonial work which includes the whole web of unequal power relations through but also beyond empire - thus, also 'meta-empire' - provides a first challenge to teaching through a postcolonial optic. A focus on the ambivalence and ambiguity of situations of imperial rule, investigating texts with attention to hybridity and mimicry in particular (cf. also Moore 2006:193-205), further complicates postcolonial pedagogics.

This contribution considers the teaching of the Gospel according to Mark from a postcolonial perspective, acknowledging the empire-postcolonial studies tension and exploring important facets in a postcolonial approach. While it has gained some ground in the last decade or so, the question rises as to how a postcolonial optic can be incorporated pedagogically. Can a postcolonial approach be part of teaching undergraduate students, and what would a postcolonial pedagogics in biblical studies look like? These and related questions are explored through indicating intersections and differences between empire and postcolonial studies in their approaches to Mark, but with special attention to postcolonialism's contributions and challenges.

\section{Teaching Mark postcolonially: Socially engaged pedagogics}

A primary question probably is: Why teach Mark with a postcolonial optic? Increasing pressure is building on the academy in general and theology/biblical studies in particular to become cognisant of and interact with its contemporary context, in South Africa but also elsewhere. Notwithstanding resistance, the scholarly tide seems to be turning from detached, aloof scholarship to socially engaged academic work. This shift offers a threshold for dealing more effectively, responsibly and accountably with contextuality, while checking remaining attempts to move away from contextuality - in all of which postcolonial biblical criticism is helpful.

Postcolonial work does not eschew attention for historical and linguistic detail in traditional exegesis, but continues the work by investigating the texts and their interpretation within ancient and modern colonised and colonising contexts. In the case of Mark, postcolonial studies wants to honour the study of historical narrative that is often identified in a threefold way: (1) the writing of history as always more and less than the past; (2) historiography accounting for the present to which the past has led, and thus a powerful instrument of community legitimation, identity formation and instruction; and, (3) that in history/writing events acquire narrative form 
(Green 2005:61-62). But a postcolonial approach is also keen to account for Roman rule in the 1st-century Mediterranean world, as empire, as structural and conceptual, differentiated and influential, and importantly, also negotiated entity. In doing so, it challenges a binary perception or a monolithic understanding of empire's role in ancient societies. ${ }^{1}$

\section{Accounting for the imperial in Mark as pedagogical point of departure}

Teaching that uses a postcolonial approach begins with the recognition of empire's impact in the 1st century and the assertion that a New Testament text like Mark cannot be understood without accounting for the power relations in which its author (and sanctioning community) was implicated. The contrast between mainstream biblical scholarship being 'restricted to theological, spiritual, and historical aspects of these narratives' while postcolonial scholarship focuses on 'the often neglected dimension of empire and the politics of imperialism' (Sugirtharajah 2012:46) may be too simple and needs further distinction. The difference may rather be in the perception of those very theological, historical and imperial elements and how they are factored into scholarly discourse. ${ }^{2}$ However, teaching Mark with attention to the religious elements of the text only and to the exclusion of the interrelationship between the Roman Empire and gospel, excludes a most central aspect of Mark's socio-political framework. In short, teaching Mark postcolonially starts with a consideration of empire vis-à-vis this gospel.

The specific interest of postcolonial pedagogics is to explore the intricate power plays behind the text, which is further compounded as they have to be approached through the power plays within the text. The empire and biblical textinterface is oblique, contingent and thus contentious, largely due to the nature of 1st-century Roman rule and the nature of the texts such as Mark's. The interface between text and empire is not necessarily built on (literary) dependence, whether conceptual (i.e., that Mark borrowed from imperial 'texts') or reactionary (i.e., that Mark's gospel primarily constitutes a response to empire in some way). The tendency to treat 'Judaism' and 'Christianity' as if they were selfcontained and autonomous entities, whose interaction with a commensurate 'pagan' imperial culture was defined by conflict, is misleading. For students to note the implausibility that the imperial context did not in some way affect the author or authoring community is as important as introducing them to research and debates on the matter. Accounting for Mark's emergence from a context infused by empire, and not

1.A further question is about incorporating the evasive and often arcane notions and terminology which marks postcolonial work as such: mimicry, colonial ambivalence, hybridity, third space, and catachresis to name a few. Useful for describing the indescribable, the infinitely complex and ever expanding and reconfigured nature inderions in in a postcolonial setting already makes for difficult understanding not to mention teaching this to (graduate) students.

2.As Sugirtharajah argues, in the Bible ' $[b]$ oth the endorsement and the censure of empire are seen as fulfilling theological purposes' (Sugirtharajah 2012:39, emphasis added). In pointing out that every political or religious human authority in Mark is a (potential) persecutor of John, Jesus or his followers, Moore $(2006: 199)$ is alert to a (potential) persecutor of John, Jesus or his followers,
the meaninglessness of such a distinction in any case. from some neutral time and space, is part of the thrust of a postcolonial optic; the focus is therefore not on an exhaustive exegetical analysis of the chosen texts.

How Mark is positioned with regard to empire is no simple question, eliciting answers that range from Mark as in direct and open opposition to empire (e.g., Horsley 2006:157) ${ }^{3}$ to apprehension of a direct counter-imperial line in Mark (e.g., Kelber 2006:98-101; Moore 2006). ${ }^{4}$ With regard to the latter, Mark may allude to an alternative to Roman imperial machinations, but in a circumspect way. '[T]he kingdom's mission in Mark to revalorize society is at most by implication opposed to Rome and careful to disguise any pronounced opposition to Roman imperial power' (Kelber 2006:98). ${ }^{5}$ Antiempire readings not only see the texts standing in an adverse relationship to empire - at times directly, at times subliminally, at times a few theological steps removed, ${ }^{6}$ but, typically, also see the relationship between empire and texts as one-sided, with empire unilaterally imposing upon the subjugated.?

Various texts in Mark lend themselves to teaching on the relationship between Mark and empire. Selecting three texts, the escalation in imperial presence and narrative tension can be demonstrated. Mark's incipit provides an interesting possible intertext with imperial inscriptions and the Priene Calendar in particular, suggesting an imperial presence in Mark 1:1. ${ }^{8}$ As one scholar put it, 'Mark appears deliberately to highlight parallels between Jesus' behavior and his treatment at the hands of the Romans, on the one hand, and Roman traditions and practices concerning the Ruler Cult, on the other' (Evans 2000:69). Interesting parallels

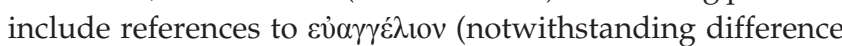

3.A particularly strong position is advocated by Richard Horsley (2006:157) (whom I quote at length): "Mark sharply opposes both alien imperial rule and its collaborators among the local "colonial" aristocracy ... Mark exhorts an indigenous people's movement of resistance to the imperial order to embody an alternative socia order In contrast with Luke-Acts Mark calls hearers/readers in the movement order ... In contrast with Luke-Acts ... Mark calls hearers/readers in the movement back to villages of Galilee (presumably to continue the project inaugurated in Jesus' ministry; $14: 23 ; 16: 7)$. Jesus and his movement take an active and uncompromising stance against the temple-state in Jerusalem.' Broadbent (2012:78) describe Horsley's approach as 'a First World type of liberation theology in its early stages' bent upon rescuing the Bible and especially Jesus and Paul from 'right-wing fundamentalists'.

4.It bears reminding that counter-imperial readings go beyond a rallying call for revolt or armed response, especially in a context where such actions were unrealistic (whether strategic-operational or goal-end result) options. The few instances of 1stcentury insurrection, locally focussed, only underlined the futility of conventiona attempts aimed at a violent overthrow of the regime.

5.Kelber later (2006:101) emphasises, 'Mark's representation of Jesus and God's kingdom is such that it studiously evades any direct confrontational engagement with Rome' It is not clear why Jesus' 'inversion of power has the effect of disarming with Rome. 'It is not clear why Jesus 'inversion of power has the effect of disarming any perceived threat to Roman power', only, and not at the same time also any perceived threative, potentially dissident discourse?

6.An anti-empire reading does not depend on either the nature (censure/resistance questioning/subversive; posing alternatives/advocating action; open/submerged or the level (harsh/subtle; pronounced/suggestive) of the perceived antipathy, subversion or resistance against empire.

7.So, for example, about Paul, Horsley (2004:23) argues that 'Paul was primarily "in but not of" the Roman imperial order', in the sense that 'he borrowed key terms and standard discourse from the dominant culture' and so 'perpetuates certain imperial images and patterns of social relations' but that he used 'imperial terms for Jesus in opposition to the imperial Roman lord and savior'.

8.The Priene Calendar inscription was made circa 9 BCE in honour of Emperor Augustus. Boring, Berger and Colpe $(1995: 169)$ are of the opinion that the use ou of $\varepsilon v a \gamma \gamma \varepsilon \lambda 10 v$ in old Greek became a general term for any message, and that the Old Testament cannot serve to explain its meaning. Followers of Jesus started to use the term soon after the time of Augustus, where it carried a profoun propaganda message of the beginning of a new era. For the inscription, see Dittenberger (1905:48-60); and http://www.artsci.wustl.edu/ fkflinn/Priene\%20 Inscription.html. 
in number), to the beginning (as noun $\dot{\alpha} \rho \chi \eta$ in Mark, and verb o $\rho \chi \varepsilon 1 v$ in the inscription), and to the messenger of the

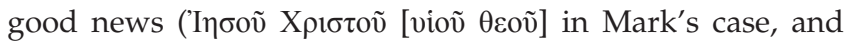
Augustus as $\sigma \omega \tau \eta \dot{\rho}$ and $\theta \varepsilon$ ćs in the inscription). Following the incipit, Jesus starts his ministry with reference to $\dot{\eta} \beta \alpha \sigma \lambda \lambda$ cía

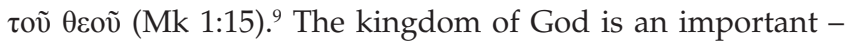
pivotal, according to Kelber (2006:98) - metaphor in Mark, and that it also has a socio-political dimension is difficult to deny. ${ }^{10}$ The stage which is set in Mark's narrative evidently includes the Roman imperial context. ${ }^{11}$

A few chapters later, it is possible to let students see through the Mark 5:1-9 narrative something of an engagement with the Roman Empire through Legion. Jesus' encounter with the Gerasene demoniac who lived between the graves attracted much empire-focused attention in the past. ${ }^{12}$ More than the single word, $\lambda \varepsilon \gamma i \omega v$ (Mk 5:9), the setting of the gospel and the passage suggests a substantial awareness of Roman imperial influence and probably also of their military occupation (e.g., Crossan 1991:314-318; Horsley 1989: 140-141, 147; Horsley 2003:100; Myers 1988:190-194; Waetjen 1989:115-118). Scholars have subsequently read the narrative in almost allegorical fashion as expressing colonising themes of land, invasion, occupation, and liberation. ${ }^{13}$ The exorcist account is (re)read amidst echoes of shattered bonds of a people's resistance, bordering on self-annihilation, against the demonising force of imperial occupation, finally driven as unclean swine into the sea (cf. Moore 2006:193-205). ${ }^{14}$

In an escalation from presence to engagement, a third passage on the question about taxes allows for the demonstration of a possible confrontational stance towards empire. The Pharisees

9. Evans $(2000: 67-81)$ points to a number of interesting parallel themes in ancient Greek, Roman and Jewish literature which can also be found in Mark, showing upon the wider and imperialist-infused notions of divine attributes, triumphs and praise and various others. The scope in which this and other terminology was used confirms the ubiquitous presence of empire in and around the 1st century.

10.But it is also a rich metaphor, 'an entity in the process of actualization whose final objective still remains to be fulfilled' (Kelber 2006:98).

11.Mark's beginning seems to signal an important opposition: 'I think we can infer that one very important aspect of the Markan evangelist's portrait of Jesus is comparison to the Roman emperor and the emperor cult' (Evans 2000:81).

12.In the Gospel according to Matthew (Mt 8:28-34) the setting for the story is the land of the Gerasenes; the narrative in Luke 8:26-39 follows the account in Mark. Space does not permit to tease out this and other interesting similarities and differences in the narratives.

13. Readings of Mark along liberation hermeneutics lines (e.g., Myers 1988; Waetjen 1989; cf. Liew 2006:206) can fall prey to what some scholars call the stagnation that characterises this approach as a whole: a preoccupation with economic matters to the exclusion of religious and cultural traditions, falling short of using the full destabilising potential of the text (Sugirtharajah 2012:45; cf. Punt 2011: $32-46)$. Broadbent (2012:69) argues that while liberation exegesis 'is well aware of the difficulties with traditional exegesis and tries to remedy those defects while trying to rescue the biblical text', postcolonial exegesis goes a further step in realising that the problem is beyond exegesis. 'The real problem is that the biblical text itself is inadequate' as Sugirtharajah (2012:38) affirms: 'The biblical attitude to the empire is a complicated one. On the one hand, empire is seen as god's instrument of liberation, but on the other, it is depicted as the object of god's opprobrium.

14.Although overt anti-Roman parlance lacks, Kelber (2006:99) suggests the following: $[/]$ t would be difficult not to acknowledge the anti-Roman sentiments. Both the intensity and the oppressiveness of violence, the naming of the demonic forces as Legion (a Roman military designation), their identification with swine (symbol of Gentile uncleanliness from a Jewish perspective), the large and precise number of swine, and, finally, their drowning in the sea add up to an unmistakably political, swine, and, finaly, the' drowning in the sea add up to an unmistakably political, anti-Roman scenario'. 'Mrk's narrative soon and the destruction of the Temple, as action against the Empire's lackeys who, as much as the masters they collo in the end, "in engineering Jesus" own obliteration in retribution for the syr destruction of their temple (11:18, cf. 14:58, 15.29-30), the local elite unwittingly and catastrophically engineers the actual destruction of the temple, according to Mark, and as such their own inevitable eradication' (Moore 2006:196).

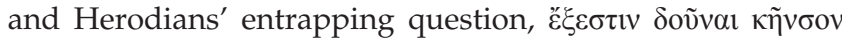

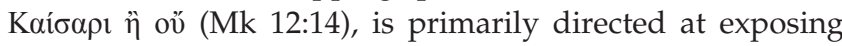
Jesus by forcing him into making an impossible choice. At the same time, however, their question not only makes empire explicit in the narrative - in fact, it assumes the evident nature of imperial influence in daily life - but it also shows a challenging attitude towards the Romans. ${ }^{15}$ Mark 12 is somewhat of a climax to a gradual emergence of the emperor in Mark, particularly in its last part. In Mark 11:27-33 where the issue of authority is debated, Jesus repudiates the temple officials and reminds them of John the Baptist's execution by Herod (Mk 6:14-29). In the next chapter they understand as an accusation against them the parable of the tenants which anticipates that Jesus will share the same fate as John (Mk 12:12). Thus far the imperium with its power of the sword and as responsible for the (anticipated) executions of both John and Jesus has remained in the background. But in Mark 12 through the emperor's image on a coin, the empire is clear for all to see. Equally clear in this scene are the collaborative efforts of empire and emperor, imperial representatives and local rulers. ${ }^{16}$

Identifying further elements of empire in these and other texts are of course possible. But is teaching on the Roman Empire sufficient in a postcolonial approach? If ' $[t]$ he primary aim of postcolonial biblical criticism is to situate empire and imperial concerns at the centre of the Bible and biblical studies' (Sugirtharajah 2012:46), is a focus on empire adequate? Talk of empire studies as a segment or variation of postcolonial studies (Broadbent 2012:78, 81) illustrates lurking tensions. On the one hand, the link between empire and postcolonial is evident and important, given the involvement of texts and their discursive potential in relation to power relations past and present. But on the other hand, it is how empire and imperial concerns are understood that determines the understanding of the particular nature and role of empire in postcolonial work. In addition to teaching students on the relationship between empire and text, the nature of that relationship is a vital focus for teaching with a postcolonial optic.

\section{Dealing with Mark amidst the vicissitudes of power}

A postcolonial optic further explores the intricate webs of power relations, particularly as they connect with (or, are

15. Here also as in Jesus' trial before the Roman prefect of Judea and his public execution at the hands of the Roman military in Mark 15:1-39 (so Moore 2006:197), Rome's face comes into focus. In a postcolonial reading the tension between an emperor who owns a coin and a god who has made a vineyard and between an emperor who owns a coin and a god who has made a vineyard and expects a harvest (Mk 12:1-12) will not go unnoticed (Liew 2007:109-110). The
accuracy of the claim that Paul appears to conflate the divine with the imperial in Romans 13, whereas in Mark 12 the domains of God and of Emperor/Empire are explicitly and deliberately separated, has to be addressed elsewhere; cf. also Moore (2006:199): 'And yet even if Mark lacks the explicitly hostile attitude toward Roman rule evident in Revelation, he also lacks the explicitly "quietist" attitude toward Roman rule evident in at least two other first-century Christian texts, namely, the letter to the Romans (cf. 13:1-7) ... and 1 Peter (cf. 2:13-17):

16. Remarks such as 'Mark's anti-imperial invective really only extends to the local elites' (Moore 2006:199) should not artificially force a divide between the Roman and local elites. The imperium required both! Is it the case that 'Mark thereby falls prey spectacularly to the divide-and-rule strategy entailed in the Roman policy of ceding administrative authority to indigenous elites in the provinces' (Moore of ceding administrative authority to indigenous elites in the provinces (Moore Judean elite too closely with the Roman authorities? Perhaps Moore's comparison Judean elite too closely with the Roman authorities? Perhaps Moore's comparison
between Mark who fights the local fight and Revelation who joins the cosmic battle predisposes him unnecessarily in this regard? 
constitutive of the phenomenon of hegemony in society. ${ }^{17}$ This is neither to deny the presence and impact of material empires nor to banalise or normalise power structures but to retain the focus on the negotiated nature of human politics, also where empire is concerned. A postcolonial optic shares a focus on empire but beyond its material manifestations also introduces students to 1st-century empire as a structural, differentiated, influential, negotiated concept (Punt 2012a: $1-11)$. It is often a difficult task to make students move beyond simplistic binaries, to abandon a naïve heroes-versus-villains scenario to texts, especially within a traditional biblical or theological studies environment. ${ }^{18}$ In this regard, teaching emphasises that also in the time of the Roman Empire, but typically of hegemonic systems, in one way or another people are linked to one another. This is not to deny victims as such (and in the process re-victimise them), but to try and understand (at least to some extent) what was involved in how people engaged and negotiated webs of power. Such webs of power are always messy and engagements with them are characterised by both the attraction (allure) as well as the repulsion of empire - and requires rethinking the nature of empire.

The Roman Empire existed as material and structural reality, comprised of and operating in terms of an important binary of centre and margins, where centre is often symbolised by a city and margins are that which are subordinated to the centre - at a political, economic or cultural level. ${ }^{19}$ But secondly, structurally empire was not a uniform phenomenon in temporal or spatial sense but was differentiated in composition and deployment regardless of many remaining similarities. ${ }^{20}$ Thirdly, the reach and power of empire was of such an extent that it influenced and impacted in direct and indirect, in overt and subtle ways, on all aspects of the lives

17.Some scholars have argued some years ago both for understanding postcolonial work as a synecdoche for empire and colonial studies, and suggested that the two might be best served through separate foci on each of the two. Segovia two might be best served through separate foci on each of the two. Segovia
(2005:23-78) suggests that imperial-colonial studies may be more appropriate than postcolonial studies, allowing wider debate, transcultural and transhistorical than postcolonis

18.The question as to where a postcolonial pedagogics is appropriate cannot be addressed here. Where will one teach with this optic, seeing that 'postcolonialism also presents wider challenges to so-called "doctrinal orthodoxy" for all religious people'? (Broadbent 2012:87). Another, maybe more cynical approach to mimicry and maybe even to the contrapuntal (on a certain level) is the realisation that many biblical texts display the tendency that in order to argue for a counterimperial setting, the existing, often earthly and material, empire has to be retained (e.g., Bird 2007:278 on Ephesians). What are the implications of this conundrum, whether Christianity can survive without imperial language, and what form Christianity will assume in a world where (neo-)colonisation has come to form Christianity will assume in a world where (neo-)colonisation has come to an end (Broadbent 2012:83)? The other side of this dangerous coin is that the discourse (13:1-37) does not, however, portend the end of the Roman imperial order, but rather its apotheosis' (Moore 2006:202).

19.As key binary or 'binomial' (Segovia) other binaries follow: civilised/uncivilised; advanced/primitive; cultured/barbarian; progressive/backward; developed/ undeveloped or underdeveloped. In the discussion of Rome and its role and impact on the communities of the early followers of Jesus, the city of Rome constitute such a metropolitan, or rather imperial, centre; and areas such as western and in particular eastern parts of the ancient world, including subcontinents such as Asia, were peripheral areas (Friesen 2001:17; see Punt 2012a).

20.Every empire is imperial in its own distinctive way since, according to Walker (2002:40): 'There are empires such as the Ottoman, based on a common religious faith, and there are religiously tolerant, pagan, and even largely secular empires, such as Rome became in its grandest centuries. There are short-lived empires, based, like that of Alexander the Great, upon raw military power. And there are empires that thrive for centuries, usually because, like Rome and Carthage, they achieve commercial prosperity that can enlist the allegiance of far-flung economic achieve commercial prosperity that can enlist the allegiance of far-flung economic
elites, or because they establish a professional civil service, an imperial governing elites, of the powerful as well as the subalterns. These and other areas of concern are sufficiently covered in empire studies.

Teaching from a postcolonial perspective takes empire's unrelenting, diverse material presence and ideological influence in all dimensions of 1st-century life across a wide geographical area further. Postcolonial work stresses two additional dimensions of empire. One is that empire was primarily a conceptual entity to which its material form(s) attest(s) - even though admitting mutuality between structure and idea does not reverse the conceptual primacy! $!^{21}$ Additionally, and contrary to restrictive, essentialist understandings of empire, it can be theorised as dynamic and primarily a process, in its conceptualising as well as its constant fabrication: a negotiated concept! ${ }^{22}$ Positions towards empire were dynamic and not static 'for' or 'against' positions, as people's interactions with empire were infinitely more complex and hybrid than merely support or opposition. ${ }^{23}$ First-century empire was a complex, intricate constellation of interrelations between the powerful and marginalised, characterised by uneven power relations and kept intact by constant social negotiations, aimed at the submission also of those on the periphery or in distant settings, by controlling land and resources. Neither monolithic nor simply imposed on passive subalterns, who had equally composite and complex profiles, empire was principally the distillation of sustained interaction between rulers and subjects, imperial forces and indigenous foreigners, with or without intermediaries (see Punt 2012a).

These engagements and negotiations postcolonial biblical studies explore as will be shown in three passages where the negotiation of power is overtly at issue. In teaching, such tensions are pointed out, teasing out various configurations (in terms of agency, e.g., 'who calls the shots', who think they do and who does; on what level?) and axes (in terms of dimensions and levels, e.g., subalterns; gender; cultural identity; social memory; to name a few) of power. It implies questioning all too easy deductions, often playing 'devil's advocate' with the students' interpretation (and their use of the scholarship or the reception history). In essence a

21.Studies of the modern phenomenon of empire also focus on empire as construct a concept, not a nation, and thus without boundaries. Applying requisite caution, the recent studies on empire by literary scholar Michael Hardt and political theorist Antonio Negri $(2000,2004)$ nevertheless add some valuable theoretical resources for theorising (about) ancient empires (see Punt 2012a).

22.Choosing against essentialising empire does not imply a disavowal of real life flesh and blood entities (e.g., Roth 2003), but points to the illusionary nature of sure categories (essentialism) and certain grounds (objectivity) (cf. Brown 2001:44); that is, to view social phenomena in terms of trans-historical essences, independent of conscious beings, disallowing the notion that society or people independent of conscious beings, disallowing the notion that
determine the categorical structure of reality (see Punt 2012a).

23.Modern empire theory provides further useful categories for theorising the Roman Empire of the 1st century, but space does not allow much further discussion. Suffice it to note that the concept of empire is unencumbered by borders as it postulates a regime that effectively encompasses all reality (the civilised world), in the total sense of the word; empire's rule extends beyond the material and therefore exercises its influence not only on human bodies but on human psychology as well; it 'creates the very world it inhabits', which includes the material or external as well as the internal world as ultimate bio-power; and, finally, the concept of empire is al inas committed to peate, which is a peace that transgresses all of ence, which is a peace that transgresses all conventional boundaries to become 'a perpetual and universal peace outside of history' (Hact \& Negri 2000:xv). And of course, at the heart of imperial peace is violence, ably support systems and manifestations of violence (cf. Punt 2012b), and the positions of Roman emperors and elite depended on their perceived ability to inflict violence (Mattern 1999), the regulatory force of the persistent threat of violence (see Punt 2012a). 
postcolonial approach moves beyond assuming a narrowly conceived empire position.

\section{Teaching hybrid identities in Mark 7:24-30 (The Syro-Phoenician woman)}

A postcolonial exploration encourages students to read Mark in a setting informed socio-politically by the Roman Empire in its various forms and formats, rather than myopically interpreting Mark as timeless theological treatise or religious tractate disconnected from 1st-century political reality. ${ }^{24}$ Such readings are not only ideologically biased but also historically poorer for it. ${ }^{25}$ A postcolonial pedagogics insists on the importance of Roman rule for understanding Mark, and the nature of Roman rule as consisting of a 'web of legitimating practices entangling Roman subjects within an imperial ideology' (Perkins 2009:1-15). But Roman rule was complicated. The elaboration of imperial ideology was done very much in the interest of a particular group in the Empire, the elite. This does not mean, however, that the Empire was an elite-driven enterprise in the simplistic sense of the word, although the elite's vital role in the Empire and in shaping ideology was always evident. In a 'unity of self-interest' the coalition of elites used imperial ideology to further their own interests. Perkins identifies in addition to the elite coalition another significant group, but on the other side of the power spectrum, namely the 'early Christians' (Perkins 2009:40). However, were the early followers of Jesus so alienated from the Roman Empire as Perkins argues, especially if their number included members of the elite?26 Teaching Mark postcolonially acknowledges such tensions within and ambivalence towards empire and the hybrid identities created, also in Mark's narrative. In addition, the effects of centuries of reception history require a discerning approach.

A biblical text is not a reservoir of theological or moral meaning, but rather 'a system of codes which interpreters must disentangle in order to reveal the hidden power relations and ideologies lurking in supposedly innocent narratives' (Sugirtharajah 2012:185). The imperial-infused

24.Kelber's (2006:101) uneasiness with the absence of explicit references denouncing the Empire does not prevent him from identifying an anti-imperial slant in Mark, but it is a tendency which he prefers to theologise: 'As for the politically imposed violence, past and present, it is reframed in a larger, a cosmic context. By transposing the source of violence into a transhistorical domain, the perspective on colonial violence is vastly broadened. The unprecedented tribulation and the demise of the temple need to be viewed in the larger context of the history of the kingdom of God and its struggle with the demonic forces of evil.'

25.The role of hidden transcripts in hegemonic contexts can be useful for explaining Kelber's acute sense of anti-Roman sentiment in Mark while none of it is overtly expressed in the gospel (Kelber 2006:98-101). Political scientist James C. Scott recognises that subtle opposition to imperial claims is necessary, as explicit recognises that subtle opposition to imperial claims is necessary, as explicit opposition can be quite dangerous to express publicly. The 'hidden transcripts'
of the oppressed is found in a 'social space in which offstage dissent to the official of the oppressed is found in a 'social space in which offstage
transcript of power relations may be voiced' (Scott 1990:xii).

26.Leander (2013) celebrates Mark's open-ended tension: '[l]ts most subversive traits can be discerned in its open and unfinished character, inviting as it does continuous re-readings that subvert the initial androcentric plot with its absentpresent women, disintegrating bread crumbs and frail disciples.' But he resolves the tension in the text, to be retained only at personal level. 'Mark represents a position that anticipates God's un-imperial empire, identifies with the margin and disturbs hegemony. To be a follower of Christ is, with Mark not a fixed and transparent affair, but one thatow and transparent affair, but one that continues to be negotiated in the present, affirming the unfinished character of the self as it searches for unexpected sign of the divine.' Moore (2006:196-197) argues that Mark can, and should - given all the anti-empire signals - on the one hand be read as resistance hiterature. But, on the other hand, one needs to 'aqua-glide over the intense ambivalence that,
on an alternative reading, can be shown ... to characterize and complicate Mark's representations of empire'. web of power relations, also between subalterns vying for power, is often characterised by ambivalence, seen in how Jesus relates to women, ${ }^{27}$ one of whom is presented in terms of hybridity. ${ }^{28}$ In the reception history of Jesus' encounter

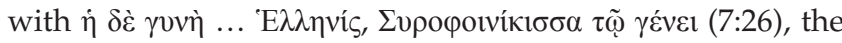
imperial interpretive heritage is surreptitiously reproduced and normalised when biblical commentaries as a rule refer to the Syro-Phoenician woman as a Gentile and her land as pagan. Keeping our focus on the text, however, this is a narrative where the importance of a gender perspective is particularly important. ${ }^{29}$ Much energy has gone into discussing the (not unimportant) breadcrumbs and dogs-metaphor, but the agency that the woman assumes and the ambivalence that characterises Jesus' position is remarkable.

Patriarchy is an enduring aspect of Mark's gospel, too, with women only becoming active participants in the narrative within the enclosed space of the domestic sphere, 'subjected to the men and the needs of the family' (Liew 2007:128). ${ }^{30}$ The Syro-Phoenician woman, however, as foreigner in her own territory approached Jesus with a clear sense of urgency, her own agency, but both are subalterns amidst bigger power plays. But her agency is remarkable in a gospel where human beings lack agency, objects upon whom others act and who do not become subjects in the full sense - the only true active agents in Mark being God and Satan (Liew 2007:123). In Mark, women 'are either passive channels of male bonding or active culprits of male discord' (Liew 2007:130). Yet in Mark 7 the Syro-Phoenician woman, in however limited a way, transgresses social conventions and steps outside Mark's narrative patterning, and acts assertively towards Jesus. In this way she becomes a hybrid figure in the narrative - hybrid in the sense of aspiring to move beyond binary thinking by allowing the inscription of agency on the subaltern, with a restructuring and destabilising of power. In a complex web of cultural interaction, forged by creatively redeploying local and imported elements, the Syro-Phoenician woman's

27. In the narrative Jesus' remarks on his impending and imperial-like parousia is placed between the story of two women who are both characterised by their
generous self-deprivation. But while Jesus stands in awe of the widow of Mark 12 and the anonymous woman with the alabaster flask of nard ointment, he does not abandon or even suspend his parousia (Moore 2006:203-204).

28.Every encounter between cultures involves an in-between space which refers to the site of conflict, interaction and mutual assimilation in such encounters. In the words of Bhabha (1994:5), 'cultures can never be defined independently because of this continual exchange that produces mutual representation of cultural difference'. Those involved do not stay the same, neither in identity no in agency. Cf. also Chidester (2000:423-437) for a discussion of hybridity as one end of a spectrum to plot identity (and agency) in postcolonial contexts, and one contrasting positions between indigeneity (and even strategic essentialism; cf. contrasting positions betwee
Spivak 1995) and hybridity.

29.Elsewhere as well, of course; cf., for example, Donaldson's remarks on how gender blindness should not be neglected in colonised contexts, with reference to the loud male Gerasene demoniac in contrast to the mute demon-possessed daughter in Mark 7:24-30 (Mt 15:21-8) (Donaldson 2005:97-113). Dube (2000:127-195) provides a close, counter-reading of the encounter between Jesus and the Canaanite woman in Matthew 15:21-28, to hear her voice; cf. also Perkinson (1996:61-85).

30.Stressing the intersection between empire and postcolonial studies is not intended to elide a number of other intersections such as gender, race, and class amidst postcolonial work on issues of power and identity. Although space does not allow their full development here, intersecting lines of, amongst others, power, identity, and gender are present in this narrative - not only regarding the Syro-Phoenician woman, but also regarding Jesus. 'Since protecting the boundaries of one's body woman, but also regarding Jesus. 'Since protecting the boundaries of one's body
constituted a key feature of ancient masculinity, the breached body of the Markan constituted a key feature of ancient masculinity, the breached body of the Markan execution, but also to Jesus' appeasement of the woman in Mark 7. Cf. Liew's valuable execution, but also to Jesus' appeasement of the woman in Mark 7. Cf. Liew's valuable
contribution on authority (also various authorities, anti-authority, new authority) in Mark, particularly in the intersections with gender (Liew 2007:106-117). 
identity and agency is re-inscribed as hyphenated, fractured and multiple. ${ }^{31}$

\section{Teaching ambivalence in Mark 8:34-9:1 (Taking up one's cross)}

Biblical scholarship, maybe not unlike other areas in the academy, is fond of invoking and treasuring its canons of research and learning, insisting on so-called core materials, scholarly consensus and basic starting points. A postcolonial angle does not deny the existence or potential value of such resources, but, in fact, acknowledges its importance for the current form and function of biblical scholarship. However, a postcolonial approach has questions and misgivings as to whether the conventional or even consensus positions either account sufficiently for their own posturing and ideological embeddedness or adequately reflect the wider berth of scholarship, particularly in the two-thirds world. Students are introduced both to a postcolonial canon of postcolonialism's own making, complete with privileged texts and sanctioned authors (Sugirtharajah 2012:26), but also encouraged to reflect critically about 'the attempt to explore the often one-sided, exploitative, and collusive nature of academic scholarship' (Sugirtharajah 2012:13). ${ }^{32}$

Teaching Mark by means of a postcolonial approach shifts canonical boundaries and takes into account that ' $[c]$ anon is a function and expression of power, specifically imperial power' (Berquist 1996:28). Moving outside the restrictions set by religious and academic canons rest on the conviction that 'truth is not confined to the text and is not singular, but can take many forms; non-Christian texts are as important as Christian texts; the biblical text is not unique or the sole bearer of truth; the voices of the marginalized are to be heard and recovered' (Broadbent 2012:61). ${ }^{33}$ However, the decision of which texts to include and on what basis introduces a range of complex issues: Are all subaltern texts or hidden manuscripts (Scott) necessarily worthy of inclusion, as if they have some pure, unadulterated form, untouched by imperial influences? Or are the texts of the marginalised always liberating, when issues of gender and class often complicate

31.The importance of women in Mark's narrative is stressed when Moore (2006:202) finds only in the parable of the widow's mites in Mark 12:41-44 - with this anonymous woman typifying the subjugated, suffering the extortive, oppressive cruelty of the indigenous, Rome-allied elites (Liew 1999:73; Horsley 2001: 216-217) - a counter-imperial apocalypse in Mark.

32. Some biblical scholars argue that it is the contravention of the traditional syllabi, and through the inclusion of what lies beyond 'the neatly defined religious and textual exclusivity of traditional exegesis' (Sugirtharajah 2012:171) that styles postcolonial exegesis as such. Postcolonial work on texts accepts a broader hermeneutical base and deliberately includes other ancient and contemporary texts, also from other religious traditions. Recently Kim (2010) connected three texts, also from other religious traditions. Recently Kim (2010) connected three strands in her work, tying together feminist, postcolonial and her own Korean contexts. She constructs a Salim hermeneutics (a strategy of 'making things
alive') for each of the narratives through a dialogue between the biblical story and the reader's use of her or his own imagination. In contrast to historical criticism's emphasis on a single, correct meaning in the biblical text, Kim's interpretative goal is making things alive, a mending of broken things, so as to open up meaning.

33.It means not to opt for rescuing the biblical text which will effectively 'reinscribe authority to one single text and exclude ... non-biblical scriptures and writings' (Broadbent 2012:81). As Moore (2006:197) argues: 'A defining feature of 'postcolonial' biblical exegesis, indeed, as distinct from (although by no means in opposition to) "liberationist" biblical exegesis, is a willingness to press a biblical text at precisely those points at which its ideology falls prey to ambivalence, text at precisely those points at which its ideology falls prey to ambivalence,
incoherence, and self-subversion - not least where its message of emancipation subtly mutates into oppression.' the other texts/voices? When does one man's emancipatory text become another woman's oppressive text?

Although only chapters away from Jesus' execution, the use of cross as metaphor in Mark 8 comes as a surprise. Crucifixion was used by the Romans equally as an apparatus of war and a means for securing their version of peace, whether eroding resistance of besieged cities, humiliating the conquered or intimidating seditious soldiers or restless provinces (Frankemölle 1992:217; Schotroff 1992:156-163).

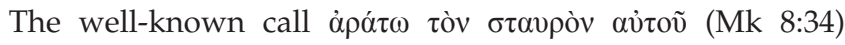
resonated differently in the 1st-century world than in later Christendom, and stands in worrying contrast to Mark 13: 14-20, all of which may already signal the imperial destruction that accompanied the Jewish War. Using the image of taking up one's cross, Mark's Jesus issues a call for loyalty to him and by implication to share in the community of Jesusfollowers complete with its social systems and configurations of power. ${ }^{34}$ In what amounts to catachresis, when subalterns take up the terminology of the powerful and adjust it for their own purposes, Mark turns the ultimate deterrent of the Empire into a symbol of a different kind of power. ${ }^{35}$

With the exception of Varro (Sat. Men. fr. 24), who cuts a lone voice in protesting against the barbarism of crucifixion, the general sentiment of the time was apparently that this form of execution was a necessary deterrent to employ against the lower classes and especially slaves, in order to discourage serious crimes (O'Collins 1992:1209; cf. Punt 2009:446-462). ${ }^{36}$ But in a dense passage (Mk 8:34-9:1) which appears to foreshadow Jesus' death but also appeals to his followers to adapt a certain perspective, lifestyle, or communal practice, Mark does not re-inscribe the cross as much as retool it. In resourceful appropriation (catachresis) he turns the rhetorical instrument of imperial power against it. It becomes a device of subversive adaptation which redirects intrusions of imperialist discourse and creates a parody of the empire through strategic misrepresentation. Mark takes up the cross and retools it for his own purposes, as is confirmed by the glory-filled parousia

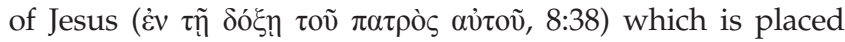
in close proximity to the reference to the cross. ${ }^{37}$ However,

34.The nature of the Markan community deserves more attention, but suffice it to mention here that unlike Samuel $(2007: 4-5,158)$, Moore (2006) and others who tend to regard Mark as the product of an already existing community. Leander (2013) reads Mark as a collective representation that interpellates the Christfollowers as a group.

35.In her discussion of the subaltern, Gayatri Spivak (1995:94-98) introduced catachresis as a concept for use in postcolonial thought, suggesting that it can describe how the colonised can recycle or redeploy parts of colonial and imperial culture and propaganda for their own purposes (and in conflict with their first, or more 'proper' uses). Cf. also Leander (2013) on Mark 8 as catachresis.

36.'As a rule the crucified man [sic] was regarded as a criminal who was receiving just and necessary punishment' (Hengel 1977:87). Notwithstanding the frequency of crucifixion in Roman times, sophisticated writers sometimes opted to avoid the topic like Tacitus who did not mention the innumerable Roman crucifixions in Palestine (Josephus, Hist. 5.8-13; cf. O'Collins 1992:1209).

37.Leander (2013) argues that the apocalyptic undertones of Mark 8 (drawing on Dan 7 and 1 Enoch 46-48; cf. Wis 1-6 and 4 Ezra 13) issues a challenge to empire. He criticises Liew's emphasis on apocalyptic as 'protest against colonialism' (Liew 199:57) to the neglect of the imperial dreams of domination over other peoples and nations (e.g., Dan 2:44; 7:14, 27; 4Q246 2:1-8) found in such anti-imperial protests. Although apocalyptic literature's revolution tends to stay imaginary it is a powerful form of resistance in situations of social powerlessness (Collin 1998.283), and reminds of Scott's hidden transcripts'. Cf. Liew (2007:106) for the widespread apocalyptic emphasis in Mark and the connections between household; 9:1, 10:29-30, 14:62 imminent kingdom; 13 little apocalypse). 
Mark's Jesus is implicated in the imperial power game. ${ }^{38}$ Teaching the ambivalence of the $\operatorname{cross}^{39}$ - which appears not to be lost on the narrator as at least the unfolding events of the show of military force and blatant mockery with political overtones in Mark 15:15-20 seem to indicate - is a challenge for which a postcolonial approach has both the discernment and an adequate vocabulary and grammar.

\section{Teaching mimicry in Mark 10:32-45 (The question by the sons of Zebedee)}

Personal orientations to teaching develop as lecturers 'shuffle their goals and access to resources', but they always 'enter the classroom with an array of resources. They have knowledge of their subject ... but they also have procedural knowledge about how things work and conceptual knowledge of how things fit together into larger systems' (Schoenfeld in Rhem 2013, my emphasis). Teaching Mark with a postcolonial optic illuminates and potentially destabilises the persisting orientalising urge in biblical scholarship. ${ }^{40}$ 'Like the Oriental discourse, biblical Orientalism has constituted itself as an object to be studied and structured and has distanced itself from the concerns of the region ... has paid little attention to what the indigenous people in the Mediterranean thought about its knowledge production' (Sugirtharajah 2012:99), leaving no room for any sense of hybridity or prevailing ambivalence.

Leaving aside that teaching already is characterised by a fair amount of ambivalence, Mark's narrative, which is cloaked in hybridity, ambivalence, and also mimicry, poses a pedagogical challenge. Homi Bhabha's (1994:92) claim that the Bible bears 'both the standard of the cross and the standard of empire', accentuates the nature of the challenge. ${ }^{41}$ The postcolonial optic cautions against narrowing the notion of empire to protest and resistance, but retains the focus on unequal power relations in 'uneven cultural equation and distorted representation' (Sugirtharajah 2012:24). Not unlike other colonial-imperial settings, Mark's narrative did not adopt a stance of unambiguous resistance towards empire

38.By promising the utter destruction of both Jewish and Roman authorities upon Jesus' eschatological return, the Markan parousia is 'in the final analysis no different from [a] "might-is-right" ideology' (Liew 1999:107); rather, it 'duplicates the authoritarian, exclusionary, and coercive politics of his colonizers' (Liew 1999:149).

39.'Far from exposing the brutality of the Roman punishment of crucifixion, the reversal of power constellations renders the crucifixion a source of strength and turns the Romans into unwitting executors of redemption' (Kelber 2006:101). In postcolonial fashion, Moore points out that 'the Markan cross ... is merely a bold entrepreneurial wager that yields an eschatological empire' (Moore 2006:203).

40.In Edward Said's ground-breaking work on the topic, he describes how the West invented the idea of the Orient and its people with the purpose both to describe the 'other' but also in that way to exercise and to legitimate control over the 'other' Orientalism as 'corporate institution for dealing with the Orient' was the mechanism by which Western colonial powers created a manageable and the mechanism by which Western colonial powers created a manageable and
controllable entity (Said 1994:3). In conjuring up the Orient, essentialist ideas dominated, 'its sensuality, its tendency to despotism, its aberrant mentality, its habits of inaccuracy, its backwardness', which were now grouped together into 'a separate and an unchallenged coherence' (Said 1994:205). Power was unilaterally exercised through this construct, wherein 'West is the actor, the Orient a passive reactor' (Said 1994:109), also raising the question not only about the possibility of representing others but the inevitable and accompanying effects (and likely, motive) of control over the 'other' (Said 1994:325-6).

41.In the words of Sugirtharajah, 'the Bible is not merely a simple spiritual text but has the capacity to foster both spiritual and territorial conquest'. And, ' $[t]$ he Christian Bible, for all its sophisticated theological ideals like tolerance and compassion, contains equally repressive and predatory elements which provide textual ammunition for spiritual and physical conquest' (Sugirtharajah 2012:31-31). Or even stronger, in an earlier work: 'the Bible itself is part of the conundrum rather than a panacea for all the ills of the postmodern/postcolonial world ... [it is] an than a panacea for all the ills of the postmodern/postcolo
unsafe and a problematic text' (Sugirtharajah 2002:100) (cf. Moore 2006:198). But postcolonial work is not motivated by a desire to sanitise the Bible. Colonial impulses are not denied or stripped from the Bible in order to present it as a counter-imperial document (Sugirtharajah 2012:171-172). ${ }^{42}$ Understanding the role of power in imperial-colonial contexts, its impact on texts such as Mark, and continuing role in the history of interpretation remain the focus. Possible emancipatory, oppressive or hegemonic tendencies in the biblical texts are acknowledged equally, trying to understand them within their particular social locations. ${ }^{43}$

In Mark 10 Jesus and the sons of Zebedee are tied into a discussion on status and authority amidst direct criticism on 'those who appear to rule over the Gentiles'. Here and elsewhere, Mark's gospel exudes an anti-authoritarian stance - with one exception. Throughout the gospel Jesus admonishes his followers to avoid aspirations towards authority, glory, power, or wealth (9:33-7; 10:17-31, 35-44; cf. 12:41-4) and the narrative undermines Jesus' select few disciples $(4: 13,40 ; 6: 52 ; 7: 18 ; 8: 21,32-3 ; 9: 5-6,33-4,38-9$; $10: 35-45 ; 14: 10-11,32-46,50,66-72)$ who could probably have claimed significant authority by the time the gospel was composed. Mark's exception is Jesus, whose position is marked by authority and power. Liew's postcolonial perspective on Mark holds that the imperialist ideology of his colonisers was taken over by Mark, even if shifting the ideological agency of power (2006:209). Mark fights power with power, so that 'Mark's Jesus may have replaced the "wicked" Jewish-Roman power, but the tyrannical, exclusionary and coercive politics goes on' (Liew 2006:215; 2007:117).

The ambivalence inherent to contexts infused by empire is expressed well by Moore (2006:204): 'In the end, then, Mark's gospel refuses to relinquish its dreams of empire, even while deftly deconstructing the models of economic exchange that enable empires, even eschatological ones, to function. ${ }^{44}$ In postcolonial analysis the role ascribed to Jesus in Mark is often described as mimicry, which wants to focus on the ambivalent mixture of deference and disobedience, and that amounts to a counter-strategy brought into play by the colonised or the subalterns: subversive subservience, subversion cloaked

42.In addition, as Sugirtharajah (2012:172) also indicates, "Postcolonial biblical criticism questions the potential of the Bible to preserve and protect the dominant and also in the process unsettles its position as a primary source for the dominant to strengthen their grip'. The Bible remains both a contested and an ambiguous collection of texts. At times Sugirtharajah's position seems less harsh, like when later on the same page he suggests that 'The hope of postcolonial exegesis is that the ancient text sheds its imperial, mystifying, archaic, and repressive image and realigns itself with postmodern, postcolonial causes' (Sugirtharajah 2012:172).

43.But the criticism can at times be harsh as much as inappropriate, for example, this claim about another gospel: 'Luke scarcely comments on the moral and social implications of the imperial rule and has nothing to say about the ethics of the origins of wealth production' (Sugirtharajah 2012:170). It is probably both culturally insensitive and anachronistic to expect criticism against imperial political and economic hegemony, even if Luke gospel's narrative world provides ample evidence of engaging the elite, the wealthy and the powerful.

44.The term ambivalence developed in psychoanalysis and refers to the simultaneous attraction toward and repulsion from an object, person or action. Ambivalence disrupts 'the clear-cut authority of colonial domination because it disturbs the simple relationship between coloniser and colonised' and describes the 'fluctuating relationship between mimicry and mockery which is fundamentally unsettling for the colonizer and is, therefore, an unwelcome aspect of colonial discourse' (Ashcroft, Griffiths \& Tiffin 1998:12). Both the coloniser and colonised find their positions marked by ambivalence: the coloniser is characterised by exploitation and positions marked by ambivalence: the coloniser is characterised by exploitation and
nurturing that are simultaneously present in the relationship with the colonised; the colonised again is never simply complicit with nor resistant to the coloniser. 
in apparent submission. ${ }^{45}$ In a recent nuanced postcolonial reading of Mark, Samuel (2007) argues that Mark negotiated a space between Roman imperial power and the comparatively dominant Jewish nationalism. ${ }^{46}$ Invoking Bhabha's notions of ambivalence and mimicry, Samuel's (2007:4-5) argument is that Mark is neither pro-colonial nor anti-colonial, but rather an ambivalent and hybrid discourse that aligns itself with but simultaneously disrupts both internal (native elite Jewish) and external (alien Roman) discourses of power.

\section{Conclusion}

Teaching with a postcolonial optic is not a strategy of arguing direct literary or historical dependence between empire and text, as empire as negotiated concept implies reciprocity or negotiation - uneven and biased and ideologically skewed as such negotiations would have been. Moving beyond the scholarly bracketing of empire and having recognised the imperial setting as the elephant in the room of 1st-century texts, one is left with the even more perilous task of attempting to understand the nature of the beast: the varied, complex web of interrelationships amongst empire, communities and people in particular social settings. ${ }^{47}$ Moreover, how does one teach the Gospel according to Mark in the 21stcentury world marked by neo-colonialism, characterised both by armed conflicts and low-intensity warfare but also by economic imperialism and cultural chauvinism, amidst calls for 'enlightened re-imperialism'? ${ }^{48}$ How does one teach postcolonial exegesis that integrates exegesis and interpretation into a single process, holding the historical and hermeneutical closely together? What knowledge, skills and attitudes would one want to communicate with and to students by means of a postcolonial optic on Mark? What does this require in terms of the expectations - regarding the teaching of Mark in content, regarding theory and approach, in terms of exegesis, and the pedagogical goals? Does this not amount to the loss of an activist angle; that an eye for complexity drives out clear challenges? As far as one answers such questions with a postcolonial optic in mind, the extent and nature to which the ubiquitous and pervasive 1st-

45. Mimicry is used to describe the nature of culture in a colonial, imperialist context: never 'pure, prior, original, unified or self-contained; it is always infected by mimicry, self-splitting, and alterity. In a word, it is always already infected by hybridity' (Bhabha 1994:85-92). As much as hybridity plays in on mimicry, hybridity is also moulded by mimicry, which functions as colonial domination and coercion. But hybridity goes beyond mimicry as it also redefines and reconstructs agency (cf. above on the portrayal of the Syro-Phoenician woman).

46.'The goal of this book is to read the story of Jesus according to Mark as a postcolonia discourse of a minoritarian community under subjection and surveillance that tries to create a space in between the Roman colonial and the relatively dominant tries to create a space in between the Roman colonial and the relatively domina

47.Sugirtharajah (2012:46-50) suggests that postcolonialism can be relevant to biblical interpretation in three areas: with regard to the relationship empire and texts, questions can be posed as to how empire is depicted (benevolent/evil), text and imperial intentions (perpetuate/contest); loyalties of an author (imperia forces/subjugated ones); representation of the occupied (victims/grateful beneficiaries); and whether the text provides space for resistance. With regard to representation, postcolonial inquiry looks at whether interpretations reflect an imperial perspective of the Western world or whether they try to unsettle colonial ambitions. A third area deals with retrieval hermeneutics, investigating three possible sources: side-lined, silenced, maligned biblical figures; imaginative ways the once-colonised formulate responses/resisted (some of the) missionary ways the once-colonised formulate responses/resisted (some of the) missionary were part of colonising endeavour but who were ambivalent about its purpose were part

48.Conservative historian, Norman Stone used the term 'enlightened re-imperialism ' in his call for 'civilized states' of the West to intervene in Africa (in Sugirtharajah 2012:171). century imperium romanum impacted on the New Testament texts will stay a topic for further debate. While empire cannot become shorthand, an all-inclusive term, for life at the time, its heuristic value for biblical scholarship is unlocked by a postcolonial optic that offers a useful approach to deal with empire in its broader sense, as negotiated concept.

In the end, teaching towards a postcolonial optic is no simple task, dealing with an approach or theory with limited consensus about its nature and operations; an approach that on top of this wants to avoid strong and exclusivist binaries and invokes ambivalence, hybridity and mimicry. Yet postcolonial theoretical perspectives can address pressing and lingering tensions without the predisposed utopian tendency to simply reverse alienation, marginalisation and disenfranchisement in postcolonial settings, which has led all too often to a mere reversal in power while leaving unevenness intact. Teaching the Gospel of Mark through a postcolonial optic opens up new possibilities for interpretation and contextualisation, but at the same time poses many challenges, pedagogically and otherwise.

\section{Acknowledgements Competing interests}

The author declares that he has no financial or personal relationships which may have inappropriately influenced him in writing this article.

\section{References}

Ashcroft, B., Griffiths, G. \& Tiffin, H., 1998, Key concepts in post-colonial studies, Routledge, London.

Berquist, J.L., 1996, 'Postcolonialism and imperial motives for canonization', Semeia 75, 15-35.

Bhabha, H.K., 1994, The location of culture, Routledge, London.

Bird, J., 2007, 'The Letter to the Ephesians', in F.F. Segovia \& R.S. Sugirtharajah (eds.), A postcolonial commentary on the New Testament writings, pp. 265-280, The Bible and Postcolonialism, vol. 13, T\&T Clark, New York, NY.

Boring, M.E., Berger, K. \& Colpe, C. (eds.), 1995, Hellenistic commentary to the New Testament, Abingdon Press, Nashville, TN.

Broadbent, R., 2012, Postcolonial Biblical Studies in Action. Origins and Trajectories. In R.S. Sugirtharajah (ed.), Exploring Postcolonial Biblical Criticism. History, Method, Practice, pp. 57-93, Wiley-Blackwell, Chicester.

Brown, D., 2001, 'Refashioning self and other: Theology, academy, and the new ethnography', in D. Brown, S.G. Davaney \& K. Tanner (eds.), Converging on culture: Theologians in dialogue with cultural analysis and criticism, pp. 41-55, Oxford Theologians in dialogue with cultural analysis and criticism, pp. 41-55, Oxford
University Press, Oxford. (AAR Reflection and theory in the study of religion series).

Chidester, D., 2000, 'Colonialism', in W. Braun \& R. McCutcheon (eds.), Guide to the study of religion, pp. 423-437, Cassell, London.

Collins, J.J., 1998, The apocalyptic imagination: An introduction to Jewish apocalyptic literature, The Biblical Resource Series, Eerdmans, Grand Rapids, MI.

Crossan, J.D., 1991, The historical Jesus: The life of a Mediterranean Jewish peasant, Harper San Francisco, San Francisco, CA

Dittenberger, W. (ed.), 1905, Orientis Graecae inscriptiones selectae. Supplementum sylloges inscriptionum graecarum, vol. 2, Hirzel, Leipzig.

Donaldson, L.E., 2005, 'Gospel hauntings: The postcolonial demons of New Testament criticims', in S.D. Moore \& F.F. Segovia (eds.), Postcolonial biblical criticism: Interdisciplinary intersections, pp. 97-113, T\&T Clark, London. (The Bible and Postcolonialism).

Dube, M.W., 2000, Postcolonial feminist interpretation of the Bible, Chalice, St Louis, $\mathrm{MO}$

Evans, C.A., 2000, 'Mark's incipit and the Priene Calendar inscription: From Jewish gospel to Greco-Roman gospel', Journal of Greco-Roman Christianity and Judaism 1, 67-81.

Frankemölle, H., 1992, 'Peace and the sword in the New Testament', in P.B. Yoder \& W.M. Swartley (eds.), transl. W. Sawatsky, The meaning of peace: Biblical studies, pp. 213-233, Westminster John Knox Press, Louisville, KY. (Studies in Peace and Scripture, vol. 2). 
Friesen, S.J., 2001, Imperial cults and the Apocalypse of John: Reading Revelation in the ruins, Oxford University Press, Oxford. http://dx.doi. Revelation in the ruins, Oxford
org/10.1093/0195131533.001.0001

Gleason, M.W., 2003, 'By whose gender standards (if anybody's) was Jesus a real man?', in S.D. Moore \& J.C. Anderson (eds.), Semeia studies: New Testament masculinities, pp. 325-327, SBL, Atlanta, GA.

Green, J.B., 2005, 'Learning theological interpretation from Luke', in C. Bartholomew, J.B. Green \& A.C. Thiselton (eds.), Reading Luke: Interpretation, reflection, formation, pp. 55-78, Scripture and Hermeneutics Series, Paternoster, Zondervan, Grand Rapids, MI.

Hardt, M. \& Negri, A., 2000, Empire, Harvard University Press, Cambridge, MA.

Hardt, M. \& Negri, A., 2004, Multitude: War and democracy in the age of empire, Penguin Books, New York, NY.

Hengel, M., 1977, Crucifixion in the ancient world and the folly of the message of the cross, SCM, London.

Horsley, R.A., 1989, Sociology and the Jesus Movement, Crossroad, New York, NY.

Horsley, R.A., 2001, Hearing the whole story: The politics of plot in Mark's gospel, Westminster John Knox Press, Louisville, KY.

Horsley, R.A., 2003, Jesus and empire: The kingdom of God and the new world disorder, Fortress Press, Minneapolis, MN

Horsley, R.A., 2004, Paul and the Roman Imperial Order, Trinity Press International, Harrisburg, PA.

Horsley, R.A., 2006, 'Renewal movements and resistance to empire in ancient Judea', in R.S. Sugirtharajah (ed.), The postcolonial biblical reader, pp. 69-77, Blackwell, London. http://dx.doi.org/10.1002/9780470775080.ch4

Kelber, W., 2006, 'Roman imperialism and early Christian scribality', in R.S. Sugirtharajah (ed.), The postcolonial biblical reader, pp. 96-111, Blackwell, London. http:// dx.doi.org/10.1002/9780470775080.ch6

Kim, S.H., 2010, Mark, women and empire: A Korean postcolonial perspective, Bible in the Modern World 20, Sheffield Phoenix Press, Sheffield.

Leander, H., 2013, Discourses of empire: The Gospel of Mark from a postcolonia perspective, SBL, Atlanta, GA. (Semeia Studies).

Liew, T.B., 1999, Politics of parousia: Reading Mark inter(con)textually, Biblical Interpretation Series, Brill, Leiden.

Liew, T.B., 2006, 'Tyranny, boundary, and might: Colonial mimicry in Mark's gospel', in R.S. Sugirtharajah (ed.), The postcolonial biblical reader, pp. 206-223, Blackwell, London. http://dx.doi.org/10.1002/9780470775080.ch14

Liew, T.B., 2007, 'The Gospel of Mark', in F.F. Segovia \& R.S. Sugirtharajah (eds.) A postcolonial commentary on the New Testament writings, The Bible and Postcolonialism, vol. 13, pp. 105-132, T\&T Clark, New York, NY.

Mattern, S.P., 1999, Rome and the enemy: Imperial strategy in the Principate, University of California Press, Berkeley, CA.

Moore, S.D., 2006, 'Mark and empire: "Zealot" and "postcolonial" readings', in R.S. Sugirtharajah (ed.), The postcolonial biblical reader, pp. 193-205, Blackwell, London. http://dx.doi.org/10.1002/9780470775080.ch13

Myers, C., 1988, Binding the strong man: A political reading of Mark's story of Jesus, Orbis, New York.
O'Collins, G., 1992, 'Crucifixion', in D.N. Freedman (ed.), Anchor Bible dictionary, vol. 1, pp. 1207-1210, Doubleday, New York, NY.

Perkins, J., 2009, Roman imperial identities in the early Christian era, Routledge Monographs in Classical Studies, Routledge, London.

Perkinson, J., 1996, 'A Canaanite word in the logos of Christ, or the difference the SyroPhoenician woman makes to Jesus', Semeia 75, 61-85.

Punt, J., 2006, 'Why not postcolonial biblical criticism in Southern Africa: Stating the obvious or looking for the impossible?' Scriptura 91, 63-82.

Punt, J., 2009, 'Cross-purposes? Violence of the cross, Galatians, and human dignity', Scriptura 102, 446-462. http://dx.doi.org/10.7833/102-0-606

Punt, J., 2011, 'Quo Vadis: Bible, hermeneutics and liberation?' Journal of Ttheology in Southern Africa 140, 35-46.

Punt, J., 2012a, 'Empire and New Testament texts: Theorising the imperial, in subversion and attraction', HTS Teologiese Studies/Theological Studies 68(1), Art. \#1182, 11 pages. http://dx.doi.org/10.4102/hts. v68i1.1182

Punt, J., 2012b, 'Violence in the New Testament, and the Roman Empire: Ambivalence, othering, agency', in P.G.R. de Villiers \& J.W. van Henten (eds.), Coping with violence in the New Testament, pp. 23-39, Brill, Leiden. (STAR, vol. 16). http:// dx.doi.org/10.1163/9789004221055_003

Rhem, J., 2013, 'Tomorrow's professor Msg.\#1254 Modeling Teaching', viewed 28 February 2013, from http://cgi.stanford.edu/ dept-ctl/cgi-bin/tomprof/posting. php?ID=1254

Roth, J.K., 2003, 'Response: Constructing and deconstructing empires', Journal of the American Academy of Religion 71(1), 121-128. http://dx.doi.org/10.1093/ jaar/71.1.121

Said, E., 1994, Orientalism, 2nd edn., Vintage, New York, NY.

Samuel, S., 2007, A postcolonial reading of Mark's story of Jesus, Library of New Testament Studies, vol. 340, T\&T Clark, Continuum, London, New York, NY.

Schotroff, L., 1992, 'The dual concept of peace', in P.B. Yoder \& W.M. Swartley (eds.), transl. W. Sawatsky, The meaning of peace: Biblical studies, pp. 156-163, Westminster John Knox Press, Louisville, KY. (Studies in Peace and Scripture, vol. 2).

Scott, J.C., 1990, Domination and the art of resistance: Hidden transcripts, Yale University Press, New Haven, CT.

Segovia, F.F., 2005, 'Mapping the postcolonial optic in biblical criticism: Meaning and scope', in S.D. Moore \& F.F. Segovia (eds.), Postcolonial biblical criticism: Interdisciplinary intersections, pp. 23-78, The Bible and Postcolonialism, T\&T Clark, London.

Spivak, G.C., 1995, 'Can the subaltern speak?' in B. Ashcroft, G. Griffiths \& H. Tiffin, The post-colonial studies reader, pp. 24-28, Routledge, London.

Sugirtharajah, R.S., 2002, Postcolonial Criticism and Biblical Interpretation, Oxford University Press, Oxford.

Sugirtharajah, R.S., 2012, Exploring postcolonial biblical criticism: History, method, practice, Wiley-Blackwell, Chicester.

Waetjen, H.C., 1989, A reordering of power: A socio-political reading of Mark's gospel, Augsburg Fortress, Minneapolis, MN

Walker, M., 2002, 'What kind of empire?', The Wilson Quarterly 26(3), 36-49. 